\title{
MODERATE SALT STRESS ON THE PHYSIOLOGICAL AND MORPHOMETRIC TRAITS OF ALOE VERA L.
}

\author{
Bernardo Murillo-Amador ${ }^{4}$, Alejandra Nieto-Garibay ${ }^{1}$, Enrique Troyo-DiéGuez ${ }^{1,4}$, \\ José Luis García-Hernández ${ }^{2}$, Luis Hernández-Montiel ${ }^{1}$ and Ricardo David Valdez-Cepeda ${ }^{3}$ \\ ${ }^{1}$ Centro de Investigaciones Biológicas del Noroeste, S.C. La Paz, Baja California Sur, México. \\ ${ }^{2}$ Universidad Juárez del Estado de Durango. Venecia, Durango, México. \\ ${ }^{3}$ Universidad Autónoma Chapingo. El Orito, Zacatecas, México. \\ ${ }^{4}$ Corresponding author: etroyo04@cibnor.mx
}

\begin{abstract}
Aloe vera L. is a perennial liliaceous plant with succulent green leaves, it is a xerophyte with economic and social value, but little is known about its response to salt stress and its mechanisms of tolerance, especially at moderate concentrations. The objective was to investigate the effect of salinity stress $(0,30,60,90$ and $120 \mathrm{mM} \mathrm{NaCl})$ on Aloe by measuring physiological and morphometric traits related to growth. The results of measuring physiological traits showed no significant differences compared to the control at 30 and $60 \mathrm{mM}$ (chlorophylls a, b, total, relative water content, net assimilation rate, specific leaf weight, and specific leaf area), even at $90 \mathrm{mM}$ or $120 \mathrm{mM}$ most parameter variations were not significantly different. Similarly, for morphological traits no significant differences were found compared to the control for all 16 morphological traits at $30 \mathrm{mM}$, or even at $60 \mathrm{mM}$ since at this concentration only one trait varied significantly (1 out of 16). Although the general trend of increasing $\mathrm{NaCl}$ was to lower leaf fresh weight as salinity increased, presumably due to a decrease in water content. However leaf dry weight was not significantly reduced at any of the salinity concentrations applied. Thus, total dry leaf biomass was basically the same or similar, this suggesting that Aloe has an ability to withstand these levels of salinity stress. It is noteworthy to point out, that there is a general trend of lower growth (lower parameters both physiological and morphological) that is not significant at low doses (30 and $60 \mathrm{mM}$ ), however becoming more significant at higher doses $(90$ and $120 \mathrm{mM})$. Thus, we suggest that Aloe has continuum responses to $\mathrm{NaCl}$ stress.
\end{abstract}

Keywords: biomass, growth analysis, $\mathrm{NaCl}$ salinity salt tolerance.

Resumen: Aloe vera L. es una planta liliácea perenne con hojas verdes suculentas, es una xerófila con valor económico y social; sin embargo, existe poca información disponible en torno a su respuesta a la salinidad y sus mecanismos de tolerancia, especialmente en concentraciones moderadas. El objetivo fue investigar el efecto del estrés salino $(0,30,60,90$ y $120 \mathrm{mM} \mathrm{de} \mathrm{NaCl})$ en rasgos fisiológicos y morfométricos relacionados con el crecimiento de Aloe. Los resultados de las características fisiológicas (clorofilas a, b, total; contenido relativo de agua; tasa de asimilación neta; peso específico de la hoja y área foliar específica), no mostraron diferencias significativas en 60 y 90 mM, comparados con el control. Incluso en 90 ó 120 mM, la variación de algunos parámetros fue diferente significativamente. Igualmente, para características morfológicas no se encontraron diferencias significativas con respecto al control en las 16 características utilizadas a $30 \mathrm{mM}$. Incluso a $60 \mathrm{mM}$ solamente una característica difirió significativamente. Aunque la tendencia general al incrementar la concentración de $\mathrm{NaCl}$ fue la disminución del peso fresco de la hoja, presumiblemente debido a la disminución del contenido de agua. Sin embargo, el peso seco de la hoja no se redujo significativamente en ninguna de las concentraciones salinas aplicadas. Así, el peso seco total de biomasa fue básicamente el mismo o similar, lo cual sugiere que Aloe tiene habilidad para soportar estos niveles de estrés por salinidad. Es de destacar que existe una tendencia general de menor crecimiento (parámetros más bajos tanto fisiológicos y morfológicos) que no son significativos a dosis bajas (30 y $60 \mathrm{mM}$ ); sin embargo, empiezan a ser más significativos a dosis más altas ( 90 y $120 \mathrm{mM}$ ). Por lo tanto, esto sugiere que Aloe tiene una respuesta continua al estrés por $\mathrm{NaCl}$.

Palabras clave: análisis de crecimiento, biomasa, salinidad por $\mathrm{NaCl}$, tolerancia a la salinidad.

$S_{i}^{a}$ alt stress is one of the most important abiotic stresses in arid and semiarid regions (Ashraf and Harris, 2004; Hebbara et al., 2003). Plants under stress have less dry matter, leaf area (Amirjani, 2011) and yield. Also it has been re- ported that salinity changes plant morphological characteristics (Zadeh and Naeini, 2007). According to FAO (2013) increased soil salinity, aquifer depletion and land degradation reduce achievable yields, thus putting at risk farmers' 
ability to bridge production gaps and improve food security. The impact of salt stress has been correlated with morphological and physiological traits like reduction in fresh and dry weight (Chartzoulakis and Klapaki, 2000). Salinity affects plant metabolism by disturbing physiological and biochemical processes of plants due to ionic and osmotic imbalances which results in the reduction of plant growth and productivity (Munns, 2005). The deleterious effects of salinity on plant growth are associated with low osmotic potential, specific ion effects, and oxidative stress, causing nutritional imbalances due nutrient or element uptake (Ashraf and Harris, 2004). Studies of plant tolerance to salt stress cover many aspects on the influences of salinity on plant response, including alterations at the morphological, physiological and molecular levels.

Aloe vera $\mathrm{L}$. is a perennial liliaceous plant with succulent green leaves joined at the stem in a whorled pattern. Among all the Aloe species, it is highly valued due to its short growth period and high economic value, and is used in pharmaceuticals, folk medicine, healthcare, cosmetic, and food products (Reynolds and Dweck, 1999). Plants are exposed to many types of environmental stresses. Among these, salinity and drought are two of the most significant problems that limit plant growth. Plants, in turn, have evolved many different physiological and biochemical strategies for coping with water stress caused by $\mathrm{NaCl}$ or drought conditions. Aloe vera is a succulent plant with crassulacean acid metabolism (CAM) adapted to arid conditions by conserving water. The most important benefit of CAM on the plant is the ability to maintain closed most of its leaf stomata during the day. This characteristic helps CAM plants be more resistant to drought stress (Rahimi-Dehgolan et al., 2012). Some experiments with Aloe have been carried out in different geographical locations for the assessment of growth, biomass, soluble carbohydrates, cations, gel, aloin content, and others variables or traits under saline stress (Karmarkar and Ranganathan, 1971; Mustafa, 1995; Tawfik et al., 2001; Sun et al., 2003; Jin et al., 2004; Xu et al., 2006; Zan et al., 2007; Silva et al., 2010; Kiran kumari et al., 2012; Moghbeli et al., 2012; Rahimi-Dehgolan et al., 2012; Rahi et al., 2013). However, the majority of these studies have used high concentrations of $\mathrm{NaCl}$ (up to $200 \mathrm{mM}$ ), high electrical conductivities, some of them up to $12 \mathrm{dS} \mathrm{m}^{-1}$, and in some cases, those studies have used $60 \%$ of sea water as a salinity treatment, with the consequence of negative effects and damages in growth, yield, physiology, morphology, and other traits and characteristics of Aloe plants. On the other hand, at present most research related to saline stress focus on glycophytes under salt stress in the laboratory, greenhouse or field; however, there are no reports about Aloe vera, a CAM desert plant, under relative mild or moderate $\mathrm{NaCl}$ stress. In general terms, when salinity is focused for selection of plants with superior tolerance to salinity, mild or moderate salinity treatments have been to use because of studies have been demonstrated that us- ing them, the effects of salinity can be more easily evaluated because of if high salinity levels are used, the majority of the plants species died and the evaluation of yield, growth and other characteristics or variables cannot be measured. Moreover, when the studies of salt-tolerant plants use mild or moderate salinity levels, the antioxidative capacity of fruits increased (D'Amico et al., 2003), with some levels of enzymes increasing such as superoxide dismutase (Keutgen and Pawelzik, 2007), causing the quality of the fruit to improve (Awang et al., 1993a,b; Keutgen and Pawelzik, 2008). Other effects measurable at mild salt stress are $\mathrm{Na}$ or $\mathrm{Cl}$ exclusion (Orsini et al., 2012), increase of biomass production (Adolf et al., 2013). Hence, moderate salinities are probably the more suitable for measuring response to growth, yield and survival (Allen et al., 1994; Munns, 2002). Also, when mild or moderate salinity levels are used, this offers the possibility of genetic improvement by selection of suitable plant material to reclaim moderately salinized lands. To improve the agricultural management of Aloe vera under the arid and semi-arid conditions of northwest of Mexico, it is important to investigate how crop growth and yield might be affected by the physiological and morphometric responses to saline stress, because of many farmlands around the coastal zone of this region are affected by sea water intrusion. Therefore, to explore the response of morphometric and physiological traits of Aloe to salt stress, plants of one cultivar of Aloe were subjected to four $\mathrm{NaCl}$ concentrations $(0,30,60,90$, and 120 $\mathrm{mM}$ ) to assess the salt tolerance of the species by analyzing the plant growth and other variables associated with plant physiology and to provide scientific basis for safe and productive cultivation of Aloe under mild saline water irrigation.

\section{Materials and methods}

Study area.- The experiment was conducted under greenhouse conditions in $\mathrm{La} \mathrm{Paz}$, located in a semiarid zone of Baja California, northwest of Mexico (24 8' 9.73" N, $110^{\circ}$ $25^{\prime} 41.73$ " W), $7 \mathrm{~m}$ above sea level. Mean, maximum and minimum temperatures in the greenhouse were 19.2, 35.3 and $5.3{ }^{\circ} \mathrm{C}$, with $60 \%$ relative humidity. The meteorological observations were obtained during the study from an automated weather station located inside the greenhouse. The experimental site has a Bw (h') hw (e) climate and is considered as a semiarid climate and sustains xerophytic vegetation. The soils are characterized by good aeration and penetrability conditions for plant roots and low-medium water retention, with high content of sand, with a neutral $\mathrm{pH}$ at the surface but that are slightly alkaline at depths of $20-60 \mathrm{~cm}$, with low organic matter content (less than $1 \%$ ).

Plant material.- Plants of uniform size, health, and color were obtained from local wild ecotype of Aloe vera L., with $30 \mathrm{~cm}$ height from the experimental field of the Centro de Investigaciones Biológicas del Noroeste, S.C. (CIBNOR). The plants were cultured in plastic pots of $25 \mathrm{~cm}$ high, 20 
$\mathrm{cm}$ wide on the upper surface, and with holes at the bottom for drainage (one plant per pot). Containing a mixture of sand and peat-moss (1:1, v:v) (Sunshine, Sun Gro Horticulture, Canada). The pots were placed in a greenhouse and cultured with natural light. After being transplanted, $1 \mathrm{~L}$ of tap water was applied every three days during $51 \mathrm{~d}$ until plant rooting was established. Uniform plants were chosen to be treated with $\mathrm{NaCl}$.

\section{Physiological traits}

Chlorophyll extraction.- Measurements of chlorophyll were performed on leaves collected from either five months old potted plant (approximately $20-30 \mathrm{~cm}$ length). Using a hole punch three disks were sampled from healthy, uniform in color and size leaves between 08:00 and 10:00 h (total area of $39.0 \mathrm{~mm}^{2}$ ). These were immediately pooled, macerated, and homogenized in $20 \mathrm{~mL}$ of cold, $80 \%$ aqueous acetone, and transported in a portable icebox to the laboratory. Chlorophyll suspensions were kept in the dark for $72 \mathrm{~h}$ prior to measuring absorbance with a spectrophotometer (Spectronic Unicom, Cambridge, United Kingdom). Before measuring absorbance, the pigment extracts were centrifuged for 3-5 min in glass tubes to make the extract fully transparent. Absorbance of leaf extracts was measured at $645 \mathrm{~nm}$ and $663 \mathrm{~nm}$, and total chlorophyll content $(C h l a+C h l b)$ was determined by the method of Arnon (1949) and expressed in terms of a leaf area basis $\left(\mathrm{mg} \mathrm{cm}^{-2}\right)$. This variable was measured four times during four months (one measurement per month) and an average was obtained.

Relative water content (RWC).- Measurements of RWC (\%) were performed on leaves collected from five months old potted plants (approximately $20-30 \mathrm{~cm}$ length). Leaves were always collected from the mid-section, in order to minimize age effects. Individual leaves were selected and three disks from the same leaves (total area of $5.10 \mathrm{~cm}^{2}$ ) were sampled using a hole-punch. The disks were then immediately weighed (fresh mass, FM). In order to obtain the turgid mass (TM), disks were floated in distilled water inside a closed Petri dish. During the imbibition period, leaf samples were weighed periodically, after gently wiping the water from the leaf surface with tissue paper. The Petri dishes were maintained under dim light (around $20 \mu \mathrm{mol} \mathrm{m}{ }^{-2}$ $\mathrm{s}^{-1}$ ) and under naturally fluctuating temperature conditions in the laboratory) which varied between $25 \pm 2{ }^{\circ} \mathrm{C}$. At the end of the imbibition period, leaf samples were placed in a pre-heated oven (Shel-Lab, model FX-5, serie-1000203, USA; Catsky, 1974; Turner, 1981), at $80{ }^{\circ} \mathrm{C}$ until constant weight (approximately $72 \mathrm{~h}$ ), in order to obtain the dry mass $(\mathrm{DM})$. All mass measurements were made using an analytical scale, with precision of $0.0001 \mathrm{~g}$ (Mettler Toledo, model AG204, USA). Values of FM, TM, and DM were used to calculate RWC, using the equation: RWC $(\%)=[(\mathrm{FM}-\mathrm{DM})$
/ (TM-DM)] $\times 100$. This variable was measured four times during four months (one measure per month) and average of the measures was obtained.

Specific leaf weight (SLW) and specific leaf area (SLA).- To calculate SLW and SLA, individual leaves were selected and three disks from the same leaves (total area of $51.0 \mathrm{~mm}^{2}$ ) were sampled using a hole-punch; after the disks were ovendried at $80^{\circ} \mathrm{C}$ until constant weight (approximately $72 \mathrm{~h}$ ) to determine dry weight $(\mathrm{mg})$. The SLA was calculated as the ratio of leaf area $\left(\mathrm{mm}^{2}\right)$ to leaf dry weight $(\mathrm{mg}), \mathrm{SLA}=$ area / dry weight, while SLW, the inverse of SLA was calculated as the ratio of leaf dry weight $(\mathrm{mg})$ to leaf area $\left(\mathrm{mm}^{2}\right)$, SLW $=$ dry weight $/$ area.

Net assimilation rate (NAR).- Once the leaves reached maturity with a size of approximately $20-30 \mathrm{~cm}$ length, for each treatment and replication a leaf was selected and NAR $\left(\mathrm{mg} \mathrm{cm} \mathrm{h}^{2}\right)$ was determined using the following procedure: at 9:00 a.m., a sample of the leaf with a punch hole of $1.7 \mathrm{~cm}$ in diameter $\left(2.27 \mathrm{~cm}^{2}\right)$ was obtained; the same day at 17:00 p.m., a second sample was obtained from the same leaf, near point close to the first sample. These samples were dried in an oven with forced air circulation at $80{ }^{\circ} \mathrm{C}$ until constant weight was obtained, to determine the dry matter production (W in $\mathrm{mg}$ ), the difference of the final weight and the initial weight of each of the samples was calculated. This dry matter production was divided between 22 which is the number of days in which such production was also considered to be able to determine the NAR (dry matter production / unit area / unit time). From the measured leaf area $\left(\mathrm{L}_{1}\right)$ and estimated dry weight $\left(\mathrm{W}_{1}\right)$ at time $\mathrm{t} 1$, the beginning of the experiment, and measured leaf area $\left(\mathrm{L}_{2}\right)$ and dry weight $\left(\mathrm{W}_{2}\right)$ at the end, time $t_{2}$, the net assimilation rate of each plant was estimated in the usual manner as NAR $\left(\mathrm{mg} \mathrm{cm}^{2} \mathrm{~d}^{-1}\right)=\left[\left(\mathrm{W}_{2}-\mathrm{W}_{1}\right)(\right.$ loge $\left.\left.\mathrm{L}_{2}-\operatorname{loge} \mathrm{L}_{1}\right)\right] /\left[\left(\mathrm{L}_{2}-\mathrm{L}_{1}\right)\left(t_{2}-t_{1}\right)\right]$.

\section{Morphological traits}

Leaf length, width, thickness, number, fresh and dry weight.- During the experimental period, mature leaves (approximately $20-30 \mathrm{~cm}$ of length) were cut at the base with a sharp knife without damage the plant. For all leaves, the next characteristics were measured: leaf length $(\mathrm{cm})$, width $(\mathrm{cm})$ which was the average of three measures done in three places along the leaf (near the base, center and the tip), thickness $(\mathrm{cm})$, which was measured in the same places where width was measured and determined using a digital caliper (General No 143, General Tools, Manufacturing Co., Inc., USA). Fresh weight (g) was determined using a conventional scale (Ohaus, model CT600-S, series 18939, USA). Each harvested leaf was placed in a pre-heated oven (Shel-Lab, model Fx-5, serie-1000203, USA), at $80^{\circ} \mathrm{C}$, until constant weight, in order to obtain the dry weight $(\mathrm{g})$. 
Table 1. Analysis of variance of physiological characteristics of Aloe vera subjected to salt stress $(\mathrm{NaCl})$. RWC $=$ relative water content, SLW $=$ specific leaf weight, SLA $=$ specific leaf area. Significant level of $F$ statistic at ${ }^{* *} P<0.01, * * * P<0.001$, ns $=$ not significant $P>0.05$.

\begin{tabular}{|c|c|c|c|c|c|c|c|c|c|c|c|c|c|c|c|}
\hline \multirow[b]{2}{*}{ Source } & \multirow[b]{2}{*}{$\mathrm{df}$} & \multicolumn{2}{|c|}{$\mathrm{Chl} \mathrm{a}$} & \multicolumn{2}{|c|}{$\mathrm{Chl} \mathrm{b}$} & \multicolumn{2}{|c|}{ Total Chl } & \multicolumn{2}{|c|}{ RWC } & \multicolumn{2}{|c|}{ SLW } & \multicolumn{2}{|c|}{ SLA } & \multicolumn{2}{|c|}{ NAR } \\
\hline & & MS & $P>F$ & MS & $\mathrm{P}>\mathrm{F}$ & MS & $P>F$ & MS & $P>F$ & MS & $P>F$ & MS & $P>F$ & MS & $P>F$ \\
\hline Salinity & 4 & 0.247 & $\mathrm{~ns}$ & 0.164 & ns & 0.464 & $\mathrm{~ns}$ & 0.3 & $\mathrm{~ns}$ & 0.0321 & $* *$ & 0.005 & $* *$ & 0.067 & $\mathrm{~ns}$ \\
\hline Error & 15 & 0.181 & & 0.076 & & 0.471 & & 0.5 & & 0.006 & & 0.001 & & 0.026 & \\
\hline
\end{tabular}

Leaf area.- Leaf area $\left(\mathrm{cm}^{2}\right)$ was measured with a Li-Cor (Li-Cor, modelo-Li-3000A, series Pam 1701, Li-Cor Lincoln, USA) portable leaf area meter. To avoid damages in the equipment due the leave thickness and weight, each leaf was drawn on a sheet paper, then cut and passed through the portable leaf area meter and leaf area registered.

Seedlings number, fresh and dry weight.- Each seedling originating from the base of the main plant was recorded, including number, their fresh and dry weight $(\mathrm{g})$.

Root number, length, fresh and dry weight.- At the end of the experiment, each main plant was harvested. For all plants, the next following characteristics were measured: root number, root length $(\mathrm{cm})$, fresh $(\mathrm{g})$ and dry weight $(\mathrm{g})$. Fresh weight was determined using a conventional scale (Ohaus, model CT600-S, series 18939, USA). Each root was placed in a pre-heated oven (Shel-Lab, model Fx-5, serie-1000203, USA), at $80^{\circ} \mathrm{C}$, until constant weight, in order to obtain the root dry weight.

Stem fresh and dry weight.- For each main plant harvested, all leaves were cut including the roots and the fresh and dry weight of each stem was measured. Stem fresh weight $(\mathrm{g})$ was determined using a conventional scale (Ohaus, model CT600-S, series 18939, USA). Each stem was placed in a pre-heated oven (Shel-Lab, model Fx-5, serie-1000203, USA) at $80{ }^{\circ} \mathrm{C}$, until constant weight was reached, in order to obtain the root dry weight (g).

Experimental design.- The saline treatments were 0, 30, 60, 90 and $120 \mathrm{mM}$ de $\mathrm{NaCl}\left(0.3,2.6,5.1,7.6\right.$ and $10.3 \mathrm{dS} \mathrm{m}^{-1}$, respectively). The experiment was established under a completely randomized design with four replications and each replication contained three pots with one plant per pot. The treatments were applied after 51 days of tap water irrigation. All plants were watered daily with an excess of appropriate saline solution with nutrients containing $\left(\mathrm{mg} \mathrm{L}^{-1}\right) 220 \mathrm{~N}, 40$ P, $200 \mathrm{~K}, 140 \mathrm{Ca}, 42 \mathrm{Mg}, 4 \mathrm{Fe}, 1.25 \mathrm{Mn}, 0.18 \mathrm{~B}, 0.23 \mathrm{Zn}$, and $0.25 \mathrm{Cu}$. Watered with an excess of solution $(500 \mathrm{~mL})$ permitted to flush the pots allowing draining the excess of solution to maintain the level of salinity. All drained solutions were collected to measure the electrical conductivity and verify that the salinity of the treatment solutions and the drained solutions were alike. The $\mathrm{pH}$ of all treatments solutions was maintained close to 6.5 by adding $\mathrm{H}_{2} \mathrm{SO}_{4}$ or $\mathrm{KOH}$. Plants were grown on average with a 12 -h photoperiod of $279 \pm 23-\mu \mathrm{mol} \mathrm{m}^{-2} \mathrm{~s}^{-1}$ photosynthetically active radiation. The length of the experiment was 150 days.

Statistical analysis.- Data was analyzed using univariate and multivariate analysis of variance (ANOVA and MANOVA)

Table 2. Analysis of variance of morphometric characteristics of Aloe vera subjected to salt stress ( $\mathrm{NaCl})$. Significant level of $\mathrm{F}$ statistic at $* P<$ $0.05 ; * * P<0.01,{ }^{* * *} P<0.001, \mathrm{~ns}=$ not significant $P>0.05$.

\begin{tabular}{|c|c|c|c|c|c|c|c|c|c|c|c|c|c|c|c|}
\hline \multirow[b]{3}{*}{ Source } & \multirow[b]{3}{*}{$\mathrm{df}$} & \multicolumn{6}{|c|}{ Seedlings } & \multicolumn{6}{|c|}{ Stems } & \multirow{2}{*}{\multicolumn{2}{|c|}{ Dry weight }} \\
\hline & & \multicolumn{2}{|c|}{ Number } & \multicolumn{3}{|c|}{ Fresh weight } & & \multicolumn{2}{|c|}{ Dry weight } & \multicolumn{4}{|c|}{ Fresh weight } & & \\
\hline & & MS & $P>F$ & & MS & $P>F$ & & MS & $P>F$ & & MS & $\mathrm{P}>\mathrm{F}$ & & MS & $P>F$ \\
\hline Salinity & 4 & 4.11 & $* *$ & & 44683.1 & $* * *$ & & 19.25 & $* * *$ & & 512.3 & ns & & 11.292 & ns \\
\hline \multirow[t]{4}{*}{ Error } & 15 & 0.872 & & & 5335.6 & & & 3.06 & & & 319.3 & & & 17.081 & \\
\hline & \multicolumn{15}{|c|}{ Leaf } \\
\hline & & \multicolumn{2}{|c|}{ Number } & \multicolumn{2}{|c|}{ Fresh weight } & \multicolumn{2}{|c|}{ Dry weight } & \multicolumn{2}{|c|}{ Length } & \multicolumn{2}{|c|}{ Area } & \multicolumn{2}{|c|}{ Thickness } & \multicolumn{2}{|c|}{ Width } \\
\hline & $\mathrm{df}$ & MS & $P>F$ & MS & $P>F$ & MS & $P>F$ & MS & $\mathrm{P}>\mathrm{F}$ & MS & $\mathrm{P}>\mathrm{F}$ & MS & $\mathrm{P}>\mathrm{F}$ & MS & $\mathrm{P}>\mathrm{F}$ \\
\hline Salinity & 4 & 0.252 & ns & 2200.8 & $* * *$ & 0.472 & ns & 35.48 & $* *$ & 731.3 & $* * *$ & 1.452 & $*$ & 0.109 & $* * *$ \\
\hline \multirow[t]{4}{*}{ Error } & 15 & 0.534 & & 323.0 & & 0.256 & & 9.78 & & 144.4 & & 0.496 & & 0.020 & \\
\hline & \multicolumn{15}{|c|}{ Roots } \\
\hline & & \multicolumn{2}{|c|}{ Number } & \multicolumn{3}{|c|}{ Length } & & \multicolumn{2}{|c|}{ Fresh weight } & \multicolumn{3}{|c|}{ Dry weight } & & & \\
\hline & $\mathrm{df}$ & MS & $P>F$ & & MS & $P>F$ & & MS & $P>F$ & & MS & $P>F$ & & & \\
\hline Salinity & 4 & 11.31 & ns & & 11.76 & ns & & 333.0 & ns & & 33.99 & ns & & & \\
\hline Error & 15 & 23.64 & & & 14.75 & & & 320.0 & & & 43.98 & & & & \\
\hline
\end{tabular}


Table 3. Effect of salt stress $(\mathrm{NaCl})$ in physiological characteristics of Aloe vera L. Values within the same column with same letters are not significantly different at $P<0.05$ (Tukey's HSD multiple range test).

\begin{tabular}{lccccccc}
\hline $\mathrm{NaCl}(\mathrm{mM})$ & $\begin{array}{c}\mathrm{Chl} \mathrm{a} \\
(\mathrm{mg} \mathrm{cm})\end{array}$ & $\begin{array}{c}\mathrm{Chl} \mathrm{b} \\
\left(\mathrm{mg} \mathrm{cm}^{2}\right)\end{array}$ & $\begin{array}{c}\text { Chl total } \\
\left(\mathrm{mg} \mathrm{cm}^{2}\right)\end{array}$ & $\begin{array}{c}\text { RWC } \\
(\%)\end{array}$ & $\begin{array}{c}\text { SLW } \\
\left(\mathrm{mm}^{2} \mathrm{mg}^{-1}\right)\end{array}$ & $\begin{array}{c}\text { SLA } \\
\left(\mathrm{mg} \mathrm{mm}^{-2}\right)\end{array}$ & $\begin{array}{c}\text { NAR } \\
\left(\mathrm{mg} \mathrm{cm}^{2} \mathrm{~d}^{-1}\right)\end{array}$ \\
\hline 0 & $4.80 \mathrm{a}$ & $2.01 \mathrm{a}$ & $6.81 \mathrm{a}$ & $97.73 \mathrm{a}$ & $1.45 \mathrm{~b}$ & $0.703 \mathrm{a}$ & $0.383 \mathrm{a}$ \\
30 & $5.38 \mathrm{a}$ & $2.23 \mathrm{a}$ & $7.62 \mathrm{a}$ & $97.80 \mathrm{a}$ & $1.54 \mathrm{ab}$ & $0.680 \mathrm{ab}$ & $0.427 \mathrm{a}$ \\
60 & $5.17 \mathrm{a}$ & $2.38 \mathrm{a}$ & $7.55 \mathrm{a}$ & $97.59 \mathrm{a}$ & $1.66 \mathrm{a}$ & $0.621 \mathrm{ab}$ & $0.593 \mathrm{a}$ \\
90 & $5.98 \mathrm{a}$ & $2.33 \mathrm{a}$ & $8.31 \mathrm{a}$ & $97.47 \mathrm{a}$ & $1.66 \mathrm{a}$ & $0.618 \mathrm{~b}$ & $0.607 \mathrm{a}$ \\
120 & $4.89 \mathrm{a}$ & $2.56 \mathrm{a}$ & $7.45 \mathrm{a}$ & $97.63 \mathrm{a}$ & $1.59 \mathrm{ab}$ & $0.638 \mathrm{ab}$ & $0.692 \mathrm{a}$ \\
\hline
\end{tabular}

for one way classification, being saline treatments $(\mathrm{NaCl})$ the study factor. The experiment was conducted using a completely randomized design with four replications. Analysis of variance and significant differences among means were determined by one way analysis of variance (ANOVA). The least significant differences Tukey's HSD test $(P=$ 0.05 ) were calculated for one way by ANOVA. In all cases, differences among means were considered significant at $P<0.05$. Before ANOVA, relative water content $(\%)$ was transformed using arcsine transformation (Sokal and Rohlf, 1995). All analyses were done with Statistica software program v 10.0 for Windows.

\section{Results}

The MANOVA analysis showed significant differences between $\mathrm{NaCl}$ treatments (Wilks $=0.000000094, F=6.34, P$ $=0.01$ ), affecting some physiological and morphometric variables. It can be seen that the relationship of Wilks possibilities is significant at the level of 0.01 . This reaffirms that there are differences between the factors in this study in some of the measured variables, and strengthens the likeli- hood that the differences observed in the univariate analysis (ANOVA) performed on the variables, are real differences and not false positives or differences that occur simply by randomized chance (Johnson, 2000).

\section{Physiological traits}

Chlorophylls.- For Chl a, Chl b and total Chl, ANOVA showed no significant differences between $\mathrm{NaCl}$ treatments (Tables 1, 3).

Relative water content (RWC).- No significant differences between $\mathrm{NaCl}$ treatments were observed in RWC (Tables $1,3)$.

Specific leaf weight (SLW) and specific leaf area (SLA).Significant differences between $\mathrm{NaCl}$ treatments were observed in SLW (Table 1). Specific leaf weight was higher at 60 and $90 \mathrm{mM} \mathrm{NaCl}$ with lower values at $0 \mathrm{mM}$ (Table 3). Significant differences of SLA were showed between $\mathrm{NaCl}$ treatments (Table 1). SLA showed higher values at $0 \mathrm{mM}$ with lower values at $90 \mathrm{mM}$ (Table 3).

Table 4. Effect of salt stress $(\mathrm{NaCl})$ in morphometric characteristics of Aloe vera L. Values within the same column with same letters are not significantly different at $P<0.05$ (Tukey's HSD multiple range test).

\begin{tabular}{|c|c|c|c|c|c|c|c|c|c|}
\hline \multirow[b]{2}{*}{$\mathrm{NaCl}(\mathrm{mM})$} & \multicolumn{3}{|c|}{ Seedlings } & \multicolumn{2}{|c|}{ Stems } & \multicolumn{4}{|c|}{ Roots } \\
\hline & Number & $\begin{array}{c}\text { Fresh weight } \\
\text { (g) }\end{array}$ & $\begin{array}{l}\text { Dry weight } \\
\text { (g) }\end{array}$ & $\begin{array}{l}\text { Fresh weight } \\
\text { (g) }\end{array}$ & $\begin{array}{l}\text { Dry weight } \\
\text { (g) }\end{array}$ & Number & $\begin{array}{l}\text { Length } \\
(\mathrm{cm})\end{array}$ & $\begin{array}{l}\text { Fresh weight } \\
\text { (g) }\end{array}$ & $\begin{array}{l}\text { Dry weight } \\
\text { (g) }\end{array}$ \\
\hline 0 & $10.04 \mathrm{a}$ & $286.05 \mathrm{a}$ & $5.93 \mathrm{a}$ & $86.70 \mathrm{a}$ & $10.27 \mathrm{a}$ & $39.41 \mathrm{a}$ & $27.83 \mathrm{a}$ & $106.41 \mathrm{a}$ & $16.60 \mathrm{a}$ \\
\hline 30 & $9.54 \mathrm{ab}$ & $217.79 \mathrm{ab}$ & $5.08 \mathrm{a}$ & $79.94 \mathrm{a}$ & $6.52 \mathrm{a}$ & $37.16 \mathrm{a}$ & 29.08 a & $106.18 \mathrm{a}$ & $10.55 \mathrm{a}$ \\
\hline 60 & $8.79 \mathrm{ab}$ & $182.73 \mathrm{ab}$ & $4.64 \mathrm{a}$ & $71.70 \mathrm{a}$ & $6.80 \mathrm{a}$ & $37.25 \mathrm{a}$ & $26.50 \mathrm{a}$ & $88.05 \mathrm{a}$ & $9.49 \mathrm{a}$ \\
\hline 90 & $8.00 \mathrm{~b}$ & $95.82 \mathrm{bc}$ & $2.63 \mathrm{ab}$ & $59.30 \mathrm{a}$ & $6.04 \mathrm{a}$ & $34.66 \mathrm{a}$ & $26.83 \mathrm{a}$ & $88.73 \mathrm{a}$ & $9.84 \mathrm{a}$ \\
\hline \multirow[t]{3}{*}{120} & $7.62 \mathrm{~b}$ & $15.70 \mathrm{c}$ & $0.48 \mathrm{~b}$ & $63.51 \mathrm{a}$ & $7.12 \mathrm{a}$ & $37.08 \mathrm{a}$ & $30.66 \mathrm{a}$ & $101.25 \mathrm{a}$ & $12.30 \mathrm{a}$ \\
\hline & & & & & Leaves & & & & \\
\hline & Number & \multicolumn{2}{|c|}{ Fresh weight $(\mathrm{g}) \quad$ D } & weight (g) & Area $(\mathrm{cm} 2)$ & \multicolumn{2}{|c|}{ Length (cm) } & ickness (cm) & Width (cm) \\
\hline 0 & $10.95 \mathrm{a}$ & \multicolumn{2}{|c|}{$126.88 \mathrm{a}$} & $3.34 \mathrm{a}$ & $119.24 \mathrm{a}$ & \multicolumn{2}{|c|}{$39.07 \mathrm{a}$} & $5.88 \mathrm{a}$ & $3.22 \mathrm{a}$ \\
\hline 30 & 10.83 a & \multicolumn{2}{|c|}{$90.94 \mathrm{ab}$} & $2.65 \mathrm{a}$ & $96.66 \mathrm{ab}$ & \multicolumn{2}{|c|}{$34.48 \mathrm{ab}$} & $5.34 \mathrm{ab}$ & $2.97 \mathrm{ab}$ \\
\hline 60 & $11.08 \mathrm{a}$ & \multicolumn{2}{|c|}{$82.77 \mathrm{~b}$} & $2.81 \mathrm{a}$ & $96.22 \mathrm{ab}$ & \multicolumn{2}{|c|}{$34.75 \mathrm{ab}$} & $4.70 \mathrm{ab}$ & $2.96 \mathrm{ab}$ \\
\hline 90 & $10.50 \mathrm{a}$ & \multicolumn{2}{|c|}{$64.82 \mathrm{~b}$} & $2.47 \mathrm{a}$ & $82.65 \mathrm{~b}$ & \multicolumn{2}{|c|}{$31.61 \mathrm{~b}$} & $4.30 \mathrm{~b}$ & $2.78 \mathrm{~b}$ \\
\hline 120 & $11.12 \mathrm{a}$ & \multicolumn{2}{|c|}{$77.19 \mathrm{~b}$} & $2.58 \mathrm{a}$ & $91.51 \mathrm{ab}$ & \multicolumn{2}{|c|}{$32.00 \mathrm{~b}$} & $5.07 \mathrm{ab}$ & $2.87 \mathrm{ab}$ \\
\hline
\end{tabular}


Net assimilation rate (NAR).- No significant differences between $\mathrm{NaCl}$ treatments were observed for NAR (Tables $1,3)$.

\section{Morphological traits}

Leaf length, width, thickness, number, fresh and dry weight.- Salinity affected some leaf characteristics. Significant differences between $\mathrm{NaCl}$ treatments were observed for leaf length (Table 2). Higher values of this variable were observed at $0 \mathrm{mM}$ and generally this variable decreased as $\mathrm{NaCl}$ increased (Table 4). Width and leaf thickness showed significant differences between $\mathrm{NaCl}$ treatments (Table 2). Both variables showed higher values at $0 \mathrm{mM}$ and lower values at $90 \mathrm{mM}$ (Table 4). No significant differences between $\mathrm{NaCl}$ treatments were observed for number of leaves (Tables 2 and 4). Leaf fresh weight showed significant differences between $\mathrm{NaCl}$ treatments (Table 2) with higher values at $0 \mathrm{mM}$ and decreasing as $\mathrm{NaCl}$ increased (Table 4). No significant differences between $\mathrm{NaCl}$ treatments were observed for leaf dry weight (Tables 2 and 4).

Leaf area.- Leaf area was affected by $\mathrm{NaCl}$ showing significant differences between $\mathrm{NaCl}$ treatments (Table 2). The higher leaf area was greater at $0 \mathrm{mM}$ followed by 30 and 60 $\mathrm{mM}$ and smallest at $90 \mathrm{mM}$ (Table 4).

Seedlings number, fresh and dry weight.- The results showed that salinity stress affected all variables related to seedlings, which showed significant differences between $\mathrm{NaCl}$ treatments (Table 2). The seedlings number increased in the main plants treated with $0 \mathrm{mM}$ and decreased as $\mathrm{NaCl}$ increased (Table 4). Fresh and dry weight showed higher values at $0 \mathrm{mM}$ and both variables decreased as $\mathrm{NaCl}$ increased (Table 4).

Root number, length, fresh and dry weight.- None of the variables related to roots showed significant differences between $\mathrm{NaCl}$ treatments (Tables 2, 4).

Stem fresh and dry weight.- None of this variable showed significant differences between $\mathrm{NaCl}$ treatments (Tables 2, 4).

\section{Discussion}

The results obtained in this study are not in agreement with other studies where they have found that chlorophyll reduces as salinity stress increased (Azooz et al., 2004; Dagar et al., 2004; Jaleel et al., 2008). The results of the present study shows that Aloe vera leaf chlorophyll content under $\mathrm{NaCl}$ stress maintain chlorophyll pigments and the stability of the pigment protein complex. Also, the salt ions do not interfere with the de novo synthesis of proteins, the structural component of chlorophyll, since it did not cause the breakdown of chlorophyll. The results suggest that $\mathrm{NaCl}$ stress has no negative effects on the photosynthetic metabolism of Aloe vera plants, at least at the $\mathrm{NaCl}$ levels tested. Other studies showed some differences of chlorophyll between Aloe species under different ecological conditions including saline water where Aloe eru had more chlorophyll than Aloe vera (Tawfik et al., 2001). The chlorophyll a/b ratio of the present study was 2.24 on average, which coincides with those reported by Tawfik et al. (2001), they reported values less than 3.0, a condition that characterizes CAM plants. On the other hand, $\mathrm{NaCl}$ treatments reduced the specific leaf area (SLA), which indicates that leaf expansion and carbon allocation were altered. Since plant physiologists have for many years used specific leaf area [SLA, area $\left(\mathrm{mm}^{2}\right) /$ dry weight (mg)] to compare the thickness and/or density of leaves, some studies have shown that SLA is primarily influenced by plant species (Cunningham et al., 1999), environment (e.g. the availability of soil moisture/nutrients and light, Li et al., 2000) and changes in photosynthetic capacity [Pinkard and Beadle, 1998 (canopy size); Reich et al., 1998 (between species)]. The SLA of the present study had higher values at $0 \mathrm{mM}$ and lower at $90 \mathrm{mM}$, at even $120 \mathrm{mM}$ the SLA was higher than at $60 \mathrm{mM}$ (Table 3). These results are in agreement with those reported by Cramer et al. (1994), and Curtis and Lauchli (1986) where they found that leaf area ratio is significantly reduced in some species under saline stress. The inverse of SLA is namely specific leaf weight (SLW) and has been used as an indicator of leaf toughness in some herbivory studies with insects (Landsberg, 1990). In the present study, the SLW was higher at two $\mathrm{NaCl}$ concentration, 60 and $90 \mathrm{mM}$, being lower at $0 \mathrm{mM}$ (Table 3) showing that this estimated parameter was not negatively affected by $\mathrm{NaCl}$ stress, contrary to that reported by Wahid (2004) who testified that in sugarcane two growth stages are affected by sodium, the leaf dry weight was more modified than leaf area, resulting in reduced SLW.

The net assimilation rate (NAR) showed no significant differences between $\mathrm{NaCl}$ treatments. These results are in agreement with those reported by Wignarajah (1990) who found that two major physiological traits enable the plants to tolerate salinity: (1) compensatory growth following adjustment to salinity, and (2) ability to increase both leaf area ratio (LAR) and net assimilation rate (NAR) to achieve this increased growth. In the same sense, Cramer et al. (1994) found in maize that relative growth rate and leaf area ratio were significantly reduced by $\mathrm{NaCl}$, but net assimilation rate was unaffected. Also, Curtis and Lauchli (1986) found in kenaf that growth analysis following nine serial harvests over 40 days showed a significant decline in leaf area ratio with salt stress but no decrease in net assimilation rate. However, other species such as tomato (Alarcon et al., 1994), and citrus (Ruiz et al., 1997), have shown significant effects of net assimilation rate due to salinity. Relative water content of Aloe was unaffected by $\mathrm{NaCl}$ treatments. Other studies with Aloe have shown significant decreasing 
trend in tissue water content, total soluble sugars and glucose when the plants were irrigated with $60 \%$ of sea water concentration as compared to fresh water (Jin et al., 2007). The relative water content of the present study shows values close to $98 \%$ which demonstrate that the water content is not affected significantly in the leaf of Aloe vera growing under this regime of moderate salt stress, results that match with those reported by Ramírez et al. (2012) and Sahu et al. (2011) who described that Aloe gel in spongy form composed of parenchymatic cells containing $>98 \%$ water concentrated with complex composition of various types of sugars, polysaccharides, phenols, and osmoprotectants. For his part, Neumann (1997) asserts that a better knowledge of the underlying physiology is required in order to understand why some species and varieties are more salt-resistant than others, which is a complex task since plant growth responses to salinity can vary with the duration and degree of stress encountered (mild, moderate, severe).

It is evident that high salinity stress could causes negative effects, which were demonstrated by Jin et al. (2007) studying the physiological and ecological characters on Aloe vera under seawater irrigation $\left(\mathrm{EC}=23.4 \mathrm{dS} \mathrm{m}^{-1}\right)$, they reported that salinity stress caused a decrease in tissue water, total soluble sugars and glucose. The salinity-tolerance and dehydration-tolerance showed by Aloe plants in the present study could be related with their metabolism, which is a crassulacean acid metabolism (CAM) plant with a specialized photosynthetic pathway (Cushman and Bohnert, 1997, 1999). This type of $\mathrm{CO}_{2}$ assimilation is very efficient because it uses the same pathway of $\mathrm{CO}_{2}$ assimilation as that found in $\mathrm{C} 4$ plants except that it occurs at night, meaning that stomata are closed during the day to avoid water loss and opened at night for $\mathrm{CO}_{2}$ uptake (Borland and Taybi, 2004; Borland et al., 2009). This type of assimilation contributes to strong dehydration-tolerance in Aloe vera, which was demonstrated by Delatorre-Herrera et al. (2010) and Silva et al. (2010) with Aloe plants that were capable of efficient osmotic adjustment during water deficit, increasing their water use efficiency, showing that $100 \%$ of field capacity, equivalent to the amount of water needed to saturate the soil, is not the best condition for the growth and yield of Aloe vera plants, because of their water use efficient increases considerably when water availability is at $75 \%$ field capacity. Although water use efficient in Aloe vera during relatively mild water deficit, plants become stressed at severe water shortage, this species are generally considered most drought and salt-tolerant compared with other Aloe species such as Aloe saponarea (Sun et al., 2003). This salt tolerance in Aloe vera could be related to high calcium and chloride content in their tissues (Ranganathan, 1970) or due to osmotic adjustment caused by the increase in protein, proline and PEP-case activity, as well as the absorption and accumulation of cations under $\mathrm{NaCl}$ stress (Murillo-Amador et al., 2014). Other studies have shown that non-halophytic succulent plants with crassulacean acid metabolism such as Aloe vera, shows diurnal variation in acid content and can synthetize more amino acids when they are subjected to mild salt concentration by metabolizing transaminases and inhibiting production of malate dehydrogenase (Karmarkar and Ranganathan, 1971). High concentrations of dissolved salts in the soil and root zone can cause the high osmotic pressure and, thus, water availability is reduced. These conditions affect physiological activities and subsequently crop yield since plants will need to spend more energy to obtain water (Hebbara et al., 2003).

All variables measured in Aloe vera leaves showed significant differences between $\mathrm{NaCl}$ treatments exhibited lower values at $90 \mathrm{mM}$ and higher values at $0 \mathrm{mM}$ (Table 4). In one study, Rahi et al. (2013) found that number of suckers, leaf numbers, and leaf biomass increased significantly during two years at 15 and 30 exchangeable sodium percentage (ESP) as compared to control and 45 ESP. This information is in line with the present findings. In the present study, even if salinity affected the majority of Aloe leaf variables, the variables do not show the classical trend of decreasing as salinity increased as expected, which could be related with the moderately salt stressed which were subjected. However, other studies have revealed that salinity affects the number of leaves, plant height, number of sprouts, root weight, plant weight, leaf weight, total gel weight, and root dry weight (Moghbeli et al., 2012) of Aloe plants subjected to 2, 4, 6 and $8 \mathrm{dS} \mathrm{m}^{-1}$ salinity. The fact that the majority of variables measured in Aloe leaves showed lower values at $90 \mathrm{mM}$ is probably because under salt stress, energy is spent on plant homeostasis instead of growth and development (Maghsoudi and Maghsoudi, 2008). On the other hand, it has been demonstrated that osmotic pressure affects cell turgidity and development; opening and closing stomata is governed by turgidity of the guard cells whereas osmotic stress, induced by salts, suppresses cell turgidity and decreases cell division and apical meristem development (Rahimi-Dehgolan et al., 2012). As A. vera has leaves with high percentage of water, cellular water loss or reduced cell volume leads to a decrease in growth. In the same sense, Rahimi-Dehgolan et al. (2012) indicated that salinity influenced to plant growth, morphological traits and biomass of Aloe when subjected to electrical conductivity of $3,6,9,12,15,18$, or $21 \mathrm{dS} \mathrm{m}^{-1}$. In the current study, seedlings were more affected by salinity because the number of seedlings, fresh and dry weight decreased as salinity increased (Table 4). These results are in agreement with the classical response of the majority of non-halophytes plants where variables decrease as salinity increases and are in agreement with those results showed in Aloe plants by Moghbeli et al. (2012) and Jin et al. (2007). Also Pasternak et al. (1986), Fuentes and Rodriguez (1988) and Fuentes et al. (1988) reported similar results showing that the height of leaves and sprouts reduced with increasing salinity in different Aloe species; however, carbohydrates 
and glycosides increased. Similar results have been reported in Agave species by De Kock (1980), Nobel and Berry (1985) and Upchurch (1981). Also Fuentes et al. (1988) reported two Aloe species that behaved favorably in soils with high salinity with little precipitation.

Results reported herein, showed that none of the variables measured in stems showed significant differences among $\mathrm{NaCl}$ treatments. These results are probably because of Aloe vera is xerophile with the characteristic that it can continue to grow and reproduce under stressed environments which is related to its adaptive physiology (Baker, 1981). Also, none of the variables measured in roots showed significant differences among $\mathrm{NaCl}$ treatments; curiously, root length was longer at $120 \mathrm{mM}$ (Table 4) which demonstrated that this variable was not negatively affected by $\mathrm{NaCl}$. Similar results were reported by Moghbeli et al. (2012) who found that Aloe plants are not able to tolerate extended periods of salinity stress while in short time spans they show some positive responses like longer root. The same authors also found that by increasing salinity stress, the plant response changed negatively, while during short periods (less than 60 days) plant respond positively to salinity stress. In other words short periods of stress are bearable, however increasing stress time eventually surpasses the degree of tolerance plant and eventually growth is reduced. This type of continuum response to increasing salt stress either by dosage or exposure was observed in this study; although the trend was visible it was not statistically significant. In addition, Mustafa (1995) suggested that in A. vera, weak dosages improve growth ( $0.1 \%$ salinity), while $0.4 \%$ salinity reduced growth parameters. Additionally, he demonstrated that the highest amounts of carbohydrates were obtained with $0.4 \%$ salinity while the highest amount of crude aloin and barbaloin were obtained with $0.2 \%$ salinity.

\section{Conclusions}

The present study reveals that Aloe vera has an ability to withstand salinity under moderate $\mathrm{NaCl}$ stress, such as that used in the present study. Although the trend was for Aloe fresh weight to decrease with salinity, dry weight did not significantly decrease indicating that biomass remained constant nevertheless there was a loss of water. In addition, even some of the morphometric traits of Aloe plants displayed higher values under $\mathrm{NaCl}$ treatments, which demonstrates that Aloe plants under moderate salt stress may respond favorably to certain dosages, similarly to what Mustafa reported in 1995. In general terms, the salinitytolerance and dehydration-tolerance showed by Aloe plants in the present study could be related to the metabolism of Aloe, which is a crassulacean acid metabolism (CAM). This study with Aloe plants reveal that using moderate salt stress, instead typical high salt stress (> $200 \mathrm{mM}$ ) offers a new perspective in which to further study salinity-resistant mechanisms of desert plants in a directed manner and may lead to creating new salt-resistant cultivars. This avoid the damages under $\mathrm{NaCl}$ treatments increasing the agronomic value of Aloe plants, making this species attractive for industrial production in arid or semiarid areas around the world with moderate salinity.

\section{Acknowledgments}

The authors thank two anonymous referees for their useful comments on an earlier version of this paper. The authors greatly appreciate the technical assistance of Lidia HiralesLucero and Carmen Mercado-Guido. This research was supported by grant AGROT1 from CIBNOR, Fundación Produce Baja California Sur, A.C., CIBNOR-UABCS and project SEP-CONACYT 180C.

\section{Literature cited}

Adolf V.I., Jacobsen S.E. and Shabala S. 2013. Salt tolerance mechanisms in quinoa (Chenopodium quinoa Willd.). Environmental and Experimental Botany 92:43-54.

Alarcon J.J., Sánchez-Blanco M.J., Bolarin M.C. and Torrecillas A. 1994. Growth and osmotic adjustment of two tomato cultivars during and after saline stress. Plant and Soil 166:75-82.

Allen J.A., Chambers J.L. and Stine M. 1994. Prospects for increasing the salt tolerance of forest trees: a review. Tree Physiology 14:843-853.

Amirjani M.R. 2011. Effect of salinity stress on growth, sugar content, pigments and enzyme activity on rice. International Journal of Botany 7:73-81.

Ashraf M. and Harris P.J.C. 2004. Potential biochemical indicators of salinity tolerance in plants. Plant Science 166:3-16.

Arnon D.I. 1949. Copper enzymes in isolated chloroplast. Polyphenoloxidase in Beta vulgaris. Plant Physiology 24:1-15.

Awang Y.B., Atherton J.G. and Taylor A.J. 1993a. Salinity effects on strawberry plants grown in rockwool. I. Growth and leaf water relations. Journal of Horticultural Science 68:783-790.

Awang Y.B., Atherton J.G. and Taylor A.J. 1993b. Salinity effects on strawberry plants grown in rockwool. II. Fruit quality. Journal of Horticultural Science 68:791-796.

Azooz M.M., Shaddad M.A. and Abdel-Latef A.A. 2004. The accumulation and compartmentation of proline in relation to salt tolerance of three sorghum cultivars. Indian Journal of Plant Physiology 9:1-8.

Baker A.J.M. 1981. Accumulators and excluders-strategies in the response of plants to heavy metals. Journal of Plant Nutrition 3:643-654.

Borland A.M. and Taybi T. 2004. Synchronization of metabolic processes in plants with Crassulacean acid metabolism. Journal of Experimental Botany 55:1255-1265.

Borland A.M., Griffiths H., Hartwell J. and Smith J.A.C. 2009. Exploiting the potential of plants with crassulacean acid metabolism for bioenergy production on marginal lands. Journal of Experimental Botany 60:2879-2896.

Catsky J. 1974. Direct methods of water content determination. In: Slavik B. Ed. Methods of Studying Plant Water Relations, pp. 121-123, Springer-Verlag, Berlin. 
Chartzoulakis K. and Klapaki G. 2000. Response of two greenhouse pepper hybrids to $\mathrm{NaCl}$ salinity during different growth stages. Scientia Horticulturae 86:247-260.

Cramer G.R., Alberico G.J. and Schmidt C. 1994. Leaf expansion limits dry matter accumulation of salt-stressed maize. Australian Journal of Plant Physiology 21:663-674.

Cunningham S.A., Summerhayes B. and Westoby M. 1999. Evolutionary divergences in leaf structure and chemistry, comparing rainfall and soil nutrient gradients. Ecological Monographs 69:569-588.

Curtis P.S. and Lauchli A. 1986. The role of leaf area development and photosynthetic capacity in determining growth of Kenaf under moderate salt stress. Australian Journal of Plant Physiology 13:553-565.

Cushman J.C. and Bohnert H.J. 1997. Molecular genetics of crassulacean acid metabolism. Plant Physiology 113:667-676.

Cushman J.C. and Bohnert H.J. 1999. Crassulacean acid metabolism: Molecular genetics. Annual Review of Plant Physiology and Plant Molecular Biology 50:305-332.

Dagar J.C., Bhagwan H. and Kumar Y. 2004. Effect on growth performance and biochemical contents of Salvadora persica when irrigated with water of different salinity. Indian Journal of Plant Physiology 9:234-238.

D’Amico M.L., Izzo R., Navari-Izzo F., Tognoni F. and Pardossi A. 2003. Sea water irrigation: antioxidants and quality of tomato berries (Lycopersicon esculentum Mill.). Acta Horticulture (ISHS) 609:59-65.

De Kock G.C. 1980. Drought-resistant fodder shrub crops in South Africa. En: Le Houérou H.N. Ed. Browse in Africa: The Current State of Knowledge. International Symposium on Browse in Africa, Addis Ababa, 8-12 April, 1980. Addis Ababa International Livestock Centre for Africa. Ethiopia.

Delatorre-Herrera J., Delfino I., Salinas C., Silva H. and Cardemil L. 2010. Irrigation restriction effects on water use efficiency and osmotic adjustment in Aloe vera plants (Aloe barbadensis Miller). Agricultural Water Management 97:1564-1570.

FAO [Food and Agriculture Organization of the United Nations]. 2013. FAO Statistical Yearbook. World food and agriculture. Rome, Italy.

Fuentes V. and Rodríguez N. 1988. Screening of tolerance to salinity among 51 medicinal species. Cuba Journal Announcement 568:14-31.

Fuentes V., Rodríguez N., Rodriguez C. and Ramos R. 1988. Salinity tolerance including Aloe arborescens and other species. Agrotecnia de Cuba 20:1-6.

Hebbara M., Rajakumar G.R., Ravishankar G. and Raghavaiah C.V. 2003. Effect of salinity stress on seed yield through physiological parameters in sunflower genotypes. Helia 26:155-160.

Jaleel C.A., Sankar B., Sridharan R. and Panneerselvam R. 2008. Soil salinity alters growth, chlorophyll content, and secondary metabolite accumulation in Catharanthus roseus. Turkish Journal of Biology 32:79-83.

Jin Z.M., Wang C.H., Liu Z.P., Gong W.J. 2007. Physiological and ecological characters studies on Aloe vera under soil salinity and seawater irrigation. Process Biochemistry 42:710-714.

Johnson D.E. 2000. Métodos Multivariados Aplicados al Análisis de Datos. International Thomson Editores, S.A. de C.V. México, D.F.

Karmarkar S.M. and Ranganathan T.P. 1971. Effect of sodium chloride on dehydrogenases and transaminases in Bryophyllum pinnatum and Aloe vera. Indian Journal of Experimental Biology 9:123-124.

Keutgen A.J. and Pawelzik E. 2007. Modifications of strawberry fruit antioxidant pools and fruit quality under $\mathrm{NaCl}$ stress. Journal of Agriculture and Food Chemistry 55:4066-4072.

Keutgen A.J. and Pawelzik E. 2008. Quality and nutritional value of strawberry fruit under long term salt stress. Food Chemistry 107:1413-1420.

Kiran kumari K.S.P., Sridevi V. and Chandana Lakshmi M.V.V. 2012: Studies on effect of salt stress on some medicinal plants. International Journal of Computational Engineering Research 2:143-149.

Landsberg J. 1990. Dieback of rural eucalypts: Does insect herbivory relate to dietary quality of tree foliage? Australian Journal of Ecology 15:73-87.

Li C.Y., Berninger F., Koskela J. and Sonninen E. 2000. Drought responses of Eucalyptus microtheca provenances depend on seasonality of rainfall in their place of origin. Australian Journal of Plant Physiology 27:231-238.

Maghsoudi M.A. and Maghsoudi K. 2008. Salt stress effects on respiration and growth of germinated seeds of different wheat (Triticum aestivum L.) cultivars. World Journal of Agricultural Sciences 4:351-358.

Moghbeli E., Fathollahi S., Salari H., Ahmadi G., Saliqehdar F., Safari A. and Grouh M.S.H. 2012. Effects of salinity stress on growth and yield of Aloe vera L. Journal of Medicinal Plants Research 6:3272-3277.

Munns R. 2002. Comparative physiology of salt and water stress. Plant, Cell \& Environment 25:239-250.

Munns R. 2005. Genes and salt tolerance: bringing them together. New Phytologist 167:645-663.

Murillo-Amador B., Córdoba-Matson M.V., Villegas-Espinoza J.A., Hernández-Montiel L.G., Troyo-Diéguez E. and García-Hernández J.L. 2014. Mineral content and biochemical variables of Aloe vera $\mathrm{L}$. under salt stress. PLOS ONE 9(4): e94870.

Munns R. 2002. Comparative physiology of salt and water stress. Plant, Cell \& Environment 25:239-250.

Mustafa M. 1995. Physiological studies on growth and active constituents of Aloe vera L. Philosophy Doctoral Thesis. Faculty of Agriculture, Zagazig University, Egypt. 176 pp.

Neumann P.M. 1997. Salinity resistance and plant growth revisited. Plant Cell \& Environment 20:1193-1198.

Nobel P.S. and Berry W.L. 1985. Element responses of Agaves. American Journal of Botany 72:686-694.

Orsini F., Alnayef M., Bona S., Maggio A. and Gianquinto G. 2012. Low stomatal density and reduced transpiration facilitate strawberry adaptation to salinity. Environmental and Experimental Botany 81:1-10.

Pasternak D., Aronson J.A. and Dov J.B. 1986. Development of new arid zone crops (Aloe sp.) for the Negev desert of Israel. Journal of Arid Environments 12:58-67.

Pinkard E.A. and Beadle C.L. 1998. Aboveground biomass partitioning and crown architecture of Eucalyptus nitens following green pruning. Canadian Journal of Forest Research 28:14191428.

Rahi T.S., Singh K. and Singh B. 2013. Screening of sodicity tolerance in Aloe vera: An industrial crop for utilization of sodic lands. Industrial Crops and Products 44:528-533.

Rahimi-Dehgolan R., Sarvestani T.Z., Rezazadeh S.A. and Dolata- 
badian A. 2012. Morphological and physiological characters of Aloe vera subjected to saline water irrigation. Journal of Herbs, Spices and Medicinal Plants 18:222-230.

Ramírez I., Estay D., Stange C. and Cardemil L. 2012. Superoxide dismutase is a critical enzyme to alleviate oxidative stress in Aloe vera (L.) Burm; plants subjected to water deficit. Plant Ecology \& Diversity 5:183-195.

Ranganathan T.P. 1970. Physiological studies in succulent plants. Master Science Dissertation. Bombay, University, India. 73 pp.

Reich P.B., Ellsworth D.S. and Walters M.B. 1998. Leaf structure (specific leaf area) modulates photosynthesis-nitrogen relations: evidence from within and across species and functional groups. Functional Ecology 12:948-958.

Reynolds T. and Dweck A.C. 1999. Aloe vera leaf gel: a review update. Journal of Ethnopharmacoly 68:3-37.

Ruiz D., Martínez V. and Cerdá A. 1997. Citrus response to salinity: growth and nutrient uptake. Tree Physiology 17:141-150.

Sahu P.K., Nema J. and Shrivastava A. 2011. Comparative performance of Aloe vera and Aloe ferox species under $\mathrm{pH}$ along with desiccation stresses. International Journal of Drug Discovery Herbal Research 1:14-17.

Silva H., Sagardia S., Sequel O., Torres C., Tapia C., Franck N. and Cardemil Z. 2010. Effect of water availability on growth and water use efficiency for biomass and gel production in Aloe vera (Aloe barbadensis M.). Industrial Crops \& Products 31:20-27.

Sokal R.R. and Rohlf F.J. 1995. Biometry. The Principles and Practice of Statistics in Biological Research. W.H. Freeman \& Co. New York.

Sun S.B., Shen Q.R., Wan J.M. and Liu Z.P. 2003. Induced expression of the gene for NADP-malic enzyme in leaves of Aloe vera L. under salt stress. Acta Biochimica et Biophysica Sinica 35:423-429.

Tawfik K.M., Sheteawi S.A. and El-Gawad Z.A. 2001. Growth and aloin production of Aloe vera and Aloe eru under different ecological conditions. Proceedings of the First International Conference (Egyptian British Biological Society, EBB Soc.) Egyptian Journal of Biology 3:149-159.

Turner N.C. 1981. Techniques and experimental approaches for the measurement of plant water status. Plant and Soil 58:339366.

Upchurch R.P. 1981. New crops for arid lands. In: Manassah J.T., Briskey E.J. Eds. Advances in Food Producing Systems for Arid and Semi-arid Lands. Part B. pp. 773-798. Academic Press, New York.

Wahid A. 2004. Analysis of toxic and osmotic effects of sodium chloride on leaf growth and economic yield of sugarcane. Botanical Bulletin Academic Sinica 45:133-141.

Wignarajah K. 1990. Growth response of Phaseolus vulgaris to varying salinity regimes. Environmental and Experimental Botany 30:141-147.

Xu C.X., Liu Y.L., Zheng Q.S. and Liu Z.P. 2006. Silicate improves growth and ion absorption and distribution in Aloe vera under salt stress. Journal of Plant Physiology and Molecular Biology 32:73-78.

Zadeh H.M. and Naeini M.B. 2007. Effects of salinity stress on the morphology and yield of two cultivars of canola (Brassica napus L.). Journal of Agronomy 6:409-414.

Zheng Q.S., Liu Z.P., Liu Y.L. and Liu L. 2004. Effects of isoosmotic salt and water stresses on growth and ionic distribution in Aloe vera seedlings. Acta Phytoecologica Sinica 28:823-827.

Received: February 23th, 2014

Accepted: May 31st, 2014 